\title{
A RECEPÇÃO DA MUDANÇA DE PARADIGMAS OCORRIDA NA FILOSOFIA DA LINGUAGEM PELO DIREITO BRASILEIRO COMO SUPERAÇÃO DO MODELO DE INTERPRETAÇÃO DE KELSEN
}

http://dx.doi.org/10.21527/2176-6622.2019.52.169-183

Recebido em: 19/9/2018

Modificações requeridas em: 7/7/2019

Aceito em: 17/7/2019

Marcio Renan Hamel

Pós-DoutoradoemDireito(URI). DoutoradoemCiênciasJurídicaseSociais(UFF). MestradoemDesenvolvimento e Especialização em Direito Privado (Unijuí). Professor na UPF. http://lattes.cnpq.br/7974769978772276 marcio@upf.br

\section{Mariane Favretto}

Graduada em Ciências Jurídicas e Sociais UPF. http://lattes.cnpq.br/5505086115717618.138875@upf.br

\section{RESUMO}

O presente artigo procura responder à questão da recepção ou não do giro ontológico-linguístico pela hermenêutica jurídica no Brasil. A recepção ocorreria como superação do modelo de interpretação kelseniano assentado no antigo paradigma da Filosofia da Consciência. As conclusões sustentam a tese de que a revolução promovida pela Filosofia da Linguagem não alcançou a hermenêutica jurídica no Brasil, de modo que ainda impera o paradigma da filosofia da consciência, fundamento do modelo positivista. Dessa forma, o modelo interpretativo kelseniano permanece sendo praticado no Direito brasileiro. O método de análise é o hermenêutico-fenomenológico, em que a compreensão e a explicação dos conceitos são elementos-chave, aliado à pesquisa bibliográfica das obras de Kelsen, bem como contando com o auxílio de literatura secundária.

Palavras-chave: Giro ontológico-linguístico. Hermenêutica. Interpretação. Kelsen.

\section{THE RECEPTION OF THE PARADIGM CHANGE OCCURRED IN THE PHILOSOPHY OF LANGUAGE} BY BRAZILIAN LAW AS A WAY TO OVERCOME KELSEN'S MODEL OF INTERPRETATION

\section{ABSTRACT}

The present article tries to answer the question of the reception or not of the ontological-linguistic turn by the legal hermeneutics in Brazil. The reception would occur as an overcoming of the model of Kelsenian interpretation, fixed on the old paradigm of the philosophy of consciousness. The conclusions supported the thesis that the revolution promoted by the philosophy of language did not reach juridical hermeneutics in Brazil, so that the paradigm of the philosophy of conscience, the foundation of the positivist model, still reigns. In this way, the Kelsenian interpretive model continues being practiced in the Brazilian Law. The method of analysis is the hermeneutic-phenomenological, where the understanding and explanation of the concepts are key elements, allied to the bibliographical research of the works of Kelsen, as well as counting on the aid of secondary literature.

Keywords: Ontological-linguistic turn. Hermeneutics. Interpretation. Kelsen.

\section{SUMÁRIO}

1. Introdução. 2. A Questão da Interpretação na Teoria Pura do Direito. 3. O Surgir de um Novo Paradigma Filosófico Informador da Interpretação. 4. A Superação do Positivismo no Direito Brasileiro por meio da Filosofia da Linguagem. 5. Considerações Finais. 6. Referências. 


\section{INTRODUÇÃO}

Não se atribui a Kelsen uma teoria da interpretação própria, entretanto o capítulo derradeiro da Teoria Pura do Direito tomou caráter de essencialidade ao estudo hermenêutico. Dessa forma, a crítica a Kelsen, promovida pelas teorias hermenêuticas modernas, perpassa, necessariamente, pela análise acertada dos escritos do jurista.

A produção da Teoria Pura do Direito deu-se no período entreguerras, em meados do século 20, destacando-se que a primeira publicação da obra ocorreu em 1934. Desde então, as ideias de Kelsen passaram a gerar controvérsias entre as variadas inteligências, muito devido às nuances existentes entre sua real produção e o que o senso comum Ihe atribui. A fim de atingir os objetivos aqui propostos, realizar-se-á um corte epistemológico para tratar da questão da interpretação tratada no capítulo VIII da referida obra.

Ainda que a primeira edição tenha sido publicada em 1934, o capítulo que trata da interpretação nela introduzido apenas no ano de 1960. Apesar disso, a questão guardou coerência com os demais conteúdos de sua produção científica, inserindo-se perfeitamente num contexto maior que é aquele da ciência do Direito, das normas escalonadas e do purismo metodológico (CADEMARTORI; GOMES, 2008, p. 102). Esses conceitos influenciaram nos desdobramentos do modelo de interpretação delineado por Kelsen.

O modelo de interpretação das normas jurídicas, trabalhado pelo jurista austríaco, assentou-se no paradigma moderno da Filosofia da Consciência, como se pretende demonstrar. Ocorre que tal paradigma restou superado após a reviravolta linguística promovida pela Filosofia da Linguagem. Desse modo, cabe analisar se o Direito brasileiro acompanhou tais mudanças ou permaneceu inerte diante delas. O objetivo será perseguido por meio do entendimento acerca da postura do poder Judiciário no país para que, ao fim, se possa atestar a superação ou não do positivismo.

Em suma, pretende-se analisar se a interpretação jurídica seguiu a evolução normativa promovida pela Constituição Federal de 1988 ou se permaneceu buscando fundamento no paradigma subjetivista moderno construído sob as bases do Direito Privado. E, neste caso, o que seria necessário à superação dos velhos paradigmas em nome da efetiva passagem para um momento pós-positivista no Direito brasileiro.

\section{A QUESTÃO DA INTERPRETAÇÃO NA TEORIA PURA DO DIREITO}

O pensamento impresso por Kelsen, em sua Teoria Pura do Direito, fora marcado pela tentativa de atribuir à ciência do Direito método e objeto próprio, garantindo ao jurista uma autonomia científica (FERRAZ JÚNIOR, 2001, p. XIV-XV). Esse pensamento ia ao encontro das ideias neopositivistas propagadas pelo Círculo de Viena, do qual Kelsen era membro no início do século 20. Os participantes do chamado empirismo lógico pretendiam "estudar questões sobre ciência, lógica e linguagem com o objetivo comum de destruir os ideais metafísicos do conhecimento científico" (DALLA BARBA; STRECK; TASSINARI, 2016, p. 16). Nesse contexto, a postura hegemônica da época atribuía o status de conhecimento científico apenas aos postulados que pudessem ser logicamente construídos e empiricamente demonstrados.

Desse modo, o pressuposto para a consagração do Direito como ciência seria a separação entre juízos de valor e juízos de fato (BOBBIO, 2006, p. 135). Dito de outro modo, seria necessário elaborar um conhecimento jurídico apartado de qualquer juízo que não fosse estritamente formal, em conformidade com a metodologia neopositivista como ciência puramente dependente da técnica. Destarte, impunha-se ao Direito a tarefa de desenvolver um conhecimento desvinculado das indagações éticas, morais e metafísicas.

O jurista admitira a conexão entre o Direito e os demais ramos do saber, porém afastou estes do âmbito de análise da Teoria do Direito. O positivismo jurídico de Kelsen não negou valor ao conteúdo do Direito, o que fez foi estabelecer que tais valorações não poderiam servir aos fins de uma teoria pura. O Direito positivo, para o autor, tem a pureza como pressuposto condicionante da sua existência, de modo que o saber jurídico, sendo autônomo, deve eximir-se da análise de elementos metajurídicos, que são capazes de contaminar a autossuficiência pretendida (WARAT, 1983, p. 32). Com base nisso, os assuntos referentes ao conteúdo das normas podem e devem ser discutidos, contanto que fora do âmbito da ciência do Direito.

No cerne do positivismo jurídico tinha-se que a validade do Direito não deveria ser condicionada à conformação com o Direito ideal, mas apenas com o Direito real, quer dizer, bastava que a norma existisse em determinado ordenamento jurídico (BOBBIO, 2006, p. 136-137). Não caberia ao jurista constatar a concordân- 
cia da norma com a moral ou a ética, bem como com qualquer outro conteúdo axiológico tendente a avaliar a justeza da norma jurídica. Nesse sentido, Kelsen afirma que "a validade de uma ordem jurídica positiva é independente da sua concordância ou discordância com qualquer sistema de moral" (2000, p. 76). Caso estivesse de acordo com aquela que é a lei máxima, ou seja, com a norma fundamental, figuraria como norma válida no interior do ordenamento normativo. Diante desses apontamentos, torna-se possível uma melhor compreensão acerca da interpretação das normas tratada em sua obra.

O positivismo normativo de Kelsen superou o positivismo exegético, o qual se firmava na proibição de interpretar. O movimento de codificação, primeiro na França (1804) e depois na Alemanha (1900), atribuiu aos Códigos Civis a fundamentação de toda a argumentação jurídica, abandonando-se o auxílio que, até então, prestava o Direito Romano. Em determinado momento, entretanto, a complexidade social não pode mais ser regulada de tal maneira, de modo que a autossuficiência dos Códigos não pode mais ser sustentada. A busca por uma solução que conferisse aplicabilidade, mas mantivesse a segurança fornecida pelos Códigos, obteve resultado, em um primeiro momento, no positivismo primitivo ou exegético e, posteriormente, no positivismo normativo (STRECK, 2010, p. 160).

Por conseguinte, a tese de que o juiz deve aplicar a lei sob a proibição de interpretar, não pertence ao positivismo normativo, mas sim à escola da exegese. A restrição imposta aos juízes, de que não poderiam, em hipótese alguma, criar o Direito, deve-se, em parte, às desavenças políticas entre Napoleão Bonaparte e a aristocracia francesa, a qual possuía muitos juízes como seus membros. Como forma de limitar os poderes dos juízes aristocratas, estabeleceu-se a tese de que o Código Civil de 1804 não deveria ser interpretado (BEDIN; LUCAS, 2015, p. 217).

Dessa maneira, o positivismo exegético fora marcado pelo fechamento semântico, separação entre o Direito e a moral e pela aposta na atribuição de um sentido exato aos signos que compunham o Código. Diante da conceituação rigorosa, o juiz era proibido de interpretar, restando liberdade apenas ao legislador. Essa forma de positivismo teve seu rigor lógico-científico enfraquecido pelas primeiras décadas do século 20 diante do aumento do poder regulatório do Estado e das consequências que daí se seguiram. Esse é o contexto em que surge a teoria de Kelsen disposta a não romper com o rigor técnico exegético, porém aprimorá-lo, passando a resolução do problema para o sentido semântico e não mais sintático (STRECK, 2010, p. 161). Assim sendo, é possível afirmar que Kelsen combateu a escola da exegese e o primado da lei sobre o juiz (MATOS; MILÃO, 2013, p. 124-125) ou o que se chama hodiernamente como juiz "boca da lei". O autor rompeu a barreira sintática e reconheceu os diversos significados dos signos linguísticos, os quais passaram a necessitar de uma definição por meio da interpretação.

O processo interpretativo pode ocorrer de maneira autêntica ou não autêntica. Aquela ocorre quando é realizada pelo Executivo, Legislativo ou Judiciário, ou seja, pelos órgãos responsáveis por aplicar o Direito. Esta, dita não autêntica, é levada a cabo pelos indivíduos e pela ciência jurídica. A partir dessa distinção, Kelsen diferencia a norma da proposição normativa. Norma é um enunciado prescritivo, produzido apenas pelos intérpretes autênticos, ou seja, aqueles a quem a norma atribui competência para aplicar o Direito. Por outro lado, as proposições jurídicas são enunciados descritivos e limitam-se ao ato de descrever o Direito apresentando-o como ele é (KELSEN, 2000, p. 388-397). Nesse sentido,

Kelsen usa o dualismo ser/dever-ser para separar o âmbito dos fatos do âmbito normativo. No âmbito dos fatos, as coisas são. Assim, em face da existência de um fato, usa-se a expressão ser para exprimir essa existência. No âmbito da normatividade, as coisas não são, mas devem ser. Quando a norma prescreve uma sanção a quem infringir seu preceito, não o faz por meio do termo ser, mas da expressão dever-ser (a norma do código penal que prescreve a pena de prisão para o infrator não prescreve que ele é punido, mas que deverá ser punido) (GOMES, 2004, p. 194).

A norma é um dever-ser, no sentido de que determina qual a conduta a ser adotada pelo homem em determinada situação (KELSEN, 2000, p. 5). Por outro lado, a proposição normativa é o juízo responsável por descrever a norma jurídica (GOMES, 2004, p. 211). A ciência jurídica utiliza-se das proposições para cumprir a sua missão de descrever o Direito. Segundo Kelsen, "a ciência jurídica não tem de aprovar ou desaprovar o seu objeto, mas apenas tem de o conhecer e descrever" (2000, p. 77). A interpretação feita pela ciência jurídica deve prezar pelo purismo metodológico, permanecendo imune às questões metajurídicas e a qualquer outro conteúdo estranho ao seu objeto. Não se admite que ultrapasse a tarefa de apresentar o Direito em seu plano 
meramente formal, ou seja, deve preocupar-se somente com o que ele é e não com o que deve ser. Por outro lado, os intérpretes autênticos, incluídos os juízes, possuem maior liberdade em seu atuar (KELSEN, 2000, p. 81), pois não há nenhum elemento vinculante capaz de controlar a aplicação da norma que se encontra dentro das fronteiras metodológicas da ciência do Direito.

A pureza, portanto, promove um corte epistemológico no Direito ao excluir de sua análise qualquer objeto estranho ao seu e, também, um corte axiológico quando assume o papel de apenas descrever seu objeto, permanecendo no campo do ser, sem cair em valorações pautadas no dever-ser. A pureza pretendida, entretanto, atinge apenas a ciência do Direito e não o Direito (CUNHA, 2008, p. 281).

Como já apontado, Kelsen admite que o Direito esteja eivado de conteúdos históricos, sociológicos e morais, porém não os encara por entender não serem questões concernentes à Teoria do Direito. Ao evitar discorrer sobre tais questões, consequentemente, não trata sobre o momento da aplicação da norma. Dessa maneira, esbarra no sacrifício que é admitir a atuação do juiz por meio de um ato de vontade dotado de conteúdos metajurídicos. As razões que levam o órgão responsável por aplicar a norma a escolher entre uma ou outra das possibilidades não são especificamente jurídicas e nem se submetem ao controle jurídico (BASILE; LAGES, 2012, p. 14).

Nesse processo, o intérprete autêntico define o sentido da norma tornando-o vinculante. Conforme Ferraz Junior, "definir, do latim finis, significa estabelecer limites, fronteiras. Essa definição, diz Kelsen, é um ato de vontade. Trata-se de um 'eu quero' e não de um 'eu sei'” (FERRAZ JúNIOR, 2003, p. 262). A decisão do intérprete autêntico não está vinculada a nada, nem mesmo à moldura normativa formada pela interpretação realizada pela ciência do Direito, como se apreende da seguinte passagem:

[...] pela via da interpretação autêntica, quer dizer, da interpretação de uma norma pelo órgão jurídico que a tem de aplicar, não somente se realiza uma das possibilidades reveladas pela interpretação cognoscitiva da mesma norma, como também se pode produzir uma norma que se situe completamente fora da moldura que a norma a aplicar representa (KELSEN, 2000, p. 394).

Para Ferraz Junior (2003), a questão da interpretação na obra de Kelsen resta sem fundamentos, pois não fornece nenhuma base para a hermenêutica dogmática. Kelsen não encara verdadeiramente a interpretação das normas, limitando-se a tratá-la como ato de vontade. Assim, "não explica a diferença entre a mera opinião, não técnica, sobre o conteúdo de uma lei, exarada por alguém que sequer tenha estudado Direito e o doutrinador, que busca, com os meios da razão jurídica, o sentido da norma" (p. 261-263).

A produção teórica de Kelsen adquiriu importância inarredável ao estudo do Direito. Mantendo inalterável essa afirmação, faz-se necessário mencionar que a questão da interpretação, tratada em sua obra mais expressiva, não coaduna com o modelo democrático, pois apresenta um decisionismo incompatível com os padrões sociais que se apregoam na atualidade.

A discricionariedade é marca da interpretação do neopositivismo de Kelsen, isso considerando que a escolha da norma a ser aplicada ao caso concreto decorre de um ato de vontade do juiz. Desse modo, torna-se possível afirmar que tal modelo interpretativo assenta-se no paradigma filosófico subjetivista da Filosofia da Consciência, desenvolvido na modernidade. Esse paradigma encontra-se superado pela Filosofia da Linguagem, de sorte que a interpretação das normas jurídicas passou a tomar contornos diversos daqueles defendidos por Kelsen na Teoria Pura do Direito, como será analisado.

\section{O SURGIR DE UM NOVO PARADIGMA FILOSÓFICO INFORMADOR DA INTERPRETAÇÃO}

A discussão acerca dos paradigmas filosóficos que norteiam o processo do conhecimento remonta à obra Crátilo, de Platão, considerada a primeira da Filosofia da Linguagem, datada do ano de 388 a.C. (STRECK, 2014, p. 177). Nela duas teorias eram confrontadas pelos personagens: a do naturalismo e a do convencionalismo. Ambas buscavam estabelecer o modo pelo qual as coisas e as palavras relacionavam-se. O naturalismo, defendido pelo personagem Hermógenes, que representava os sofistas, acreditava em uma ligação natural entre coisas e palavras, a natureza é que ditava o nome das coisas. De outro modo, o convencionalismo, defendido pelo personagem Heráclito, seguia o sentido de que a relação ocorreria por meio de uma convenção, consolidando-se pelo uso. O personagem de Sócrates adotava posição intermediária entre aquelas citadas, expressando a concepção de Platão a respeito da linguagem (PLATÃO, 1994, p. 155-156). 
Segundo o Sócrates de Platão, o modo pelo qual se dava a linguagem era um limitador para ambas as teorias, que seguiam caminhos extremos. Criticava a Teoria Convencionalista por não se poder conceber uma linguagem que é imposta, argumentando que, ao contrário, ela desenvolver-se-ia naturalmente, nos mais diversos segmentos sociais, como um hábito. De outro lado, a teoria contrária também era criticada pelo Sócrates platônico, na medida em que este afastava o desejo de que as palavras pudessem descrever fielmente as coisas (GADAMER, 2014, p. 525).

Nesse sentido, a posição de Platão, para quem caberia ao sábio legislador dar nome às coisas, aproximava-se da dos sofistas e do convencionalismo, entretanto aduzia que a nomeação das coisas não seguiria a vontade do legislador, mas sim a um modelo que determinaria suas escolhas. Desse entendimento exsurge uma das mais importantes teses de Platão: as coisas devem ser conhecidas em si mesmas, independentemente da palavra, ou seja, sem a intermediação da linguagem. Em razão disso, a linguagem é colocada em segundo plano, funcionando como mero instrumento e não como constitutiva do sentido (STRECK, 2014, p. 181).

O pensamento metafísico clássico, expressado por Platão, concebia a metafísica como "ciência primeira", isso por funcionar como fundamento de todas as demais ciências. Ao lograr esse entendimento, as coisas possuíam uma essência inerente, isso quer dizer "que os sentidos estavam nas coisas" (STRECK, 2013, p. 13). Somente por meio do objeto e da sua essência é que o sentido poderia ser alcançado. Renegava-se, portanto, importância à linguagem, que funcionava como mero instrumento dispensável para a constituição do sentido.

Em vista disso, a hermenêutica pode ser pensada apenas após o surgimento da modernidade e do sujeito moderno dotado de racionalidade. A busca pelo sentido das coisas deslocou-se do objeto para o sujeito, de sorte que caberia a este extrair o sentido da norma e não apenas descrevê-lo, "é o que se pode denominar de esquema sujeito-objeto, em que o mundo passa a ser explicado (e fundamentado) pela razão" (STRECK, 2013, p. 13). Desse modo, embora não se olvide das contribuições epistemológicas fornecidas por importantes pensadores do medievo, promover-se-á um salto na História que levará ao início da Modernidade com o surgimento do sujeito cartesiano.

A noção de sujeito proposta por Descartes fornecera razão ao surgimento da metafísica moderna (GUGEL, 2014, p. 129). O objetivo do filósofo era contrapor as incertezas da época, pois havia um ceticismo quanto à capacidade do homem para encontrar as respostas certas nas ciências, isso considerando a existência de um momento de crise no pensamento científico. Ao não se render ao ceticismo, o autor empregou seus esforços na busca pela verdade irrefutável, ou seja, por um conhecimento que, produzido racionalmente, não poderia ser contestado.

O método cartesiano surge, portanto, da busca de Descartes por imprimir um rigor matemático na Filosofia. Na elaboração desse método o autor, em um primeiro momento, estabelece a dúvida sobre todas as coisas, inclusive sobre os sentidos. Considera que até mesmo a mente possa funcionar como articuladora de ilusões, impedindo a distinção do que é ou não real. Já no momento seguinte, em meio ao solipsismo, o filósofo chega à conclusão de que ao menos uma coisa poderia lograr como uma certeza: se duvidava era por ser capaz de pensar e, se pensava, constituir-se-ia como algo que existe. Nas palavras do autor: "não há, pois, dúvida alguma de que sou, se ele me engana; e, por mais que me engane, não poderá jamais fazer com que eu nada seja, enquanto eu pensar ser alguma coisa" (DESCARTES, 2005, p. 18).

Desse modo, mesmo que estivesse sendo enganado a respeito de tudo o que conhecia, não poderia ser enganado sobre o fato de existir, pois isso restava provado em sua consciência. Foi a partir dessa descoberta que Descartes rebateu o ceticismo ao apresentar um novo fundamento para a formação do pensamento científico: a racionalidade do sujeito expressa por meio do argumento do Cogito (Cogito ergo sum), traduzido como "penso, logo existo". Conforme o autor, somente o sujeito emergido em si mesmo e na sua consciência seria capaz de alcançar a verdade irrefutável (MARCONDES, 2007, p. 181-184).

Todas as coisas externas ao pensamento deveriam ser ignoradas, pois desprovidas de certeza, inclusive o próprio corpo assim considerado pelo autor: "tenho uma ideia distinta do corpo, na medida em que é apenas uma coisa extensa e que não pensa, é certo que este eu, isto é, minha alma, pela qual eu sou o que sou, é inteira e verdadeiramente distinta de meu corpo e que ela pode ser ou existir sem ele" (DESCARTES, 2000, p. 55). 


\section{Debate}

Por conseguinte, o filósofo cria uma teoria racionalista em que a razão torna-se responsável pela formação do conhecimento científico. Nesse ponto, supera a dependência ao divino vivida na Idade Média e abre uma clareira no pensamento da época ao anunciar o surgimento do sujeito moderno. O método cartesiano, momento da subjetividade, seria responsável por salvaguardar a certeza da ciência, livrando-a de qualquer equívoco.

A verdade, portanto, encontrava-se na consciência do sujeito pensante. Dessa maneira, Descartes ignorou a importância da linguagem como intermediadora da relação com o mundo e conferiu ao sujeito, isolado e emergido em sua subjetividade, a missão de constituir o sentido das coisas. Em suma, "o argumento do cogito o coloca diante do solipsismo, um idealismo radical que significa o isolamento da consciência (interioridade) em relação ao mundo exterior" (MARCONDES, 2007, p. 195).

Kant representou outro marco para a modernidade, pois foi ele quem promoveu uma revolução copernicana no seio do paradigma da Filosofia da Consciência. A Crítica da Razão Pura procura estabelecer o modo pelo qual sujeito e objeto relacionam-se para a formação do conhecimento. Desse modo, ocupa-se não somente com o estudo acerca dos objetos, mas também com o modo pelo qual ocorre a relação entre eles e o sujeito, uma Filosofia, portanto, transcendental (KANT, 1987, p. 26). Suas afirmações acerca dessa relação seguiram no sentido contrário da concepção até então vigente de que seria o sujeito que giraria em torno do objeto (PEDRON, 2011, p. 174). Segundo o autor, "o objeto dos sentidos se regula pela nossa faculdade de intuição" (KANT, 1987, p. 17).

O autor acabou por afastar a ideia de que o sentido seria obtido por meio da essência dos objetos, passando a creditar essa apreensão ao sujeito e sua racionalidade. Somente por meio da sensibilidade e do entendimento é que o objeto poderia ser conhecido. Assim, conforme o filósofo: "sem sensibilidade nenhum objeto nos seria dado, e sem entendimento nenhum seria pensado" (KANT, 1987, p. 75). Ambos deveriam atuar concomitantemente para a obtenção do conhecimento.

Tendo como ponto central o sujeito, a linguagem continuou em segundo plano. Para Kant, a linguagem tem "uma função auxiliar, uma vez que a função principal é reservada ao pensamento". Desse modo, Kant nega o protagonismo da linguagem na constituição da compreensão, considerando as palavras representações do que realmente é dotado de sentido (STRECK, 2014, p. 204). Outrossim, a interação do sujeito com o mundo não era ponto a compor as principais ideias da época, ao contrário, a desconsideração do protagonismo da linguagem resultava na própria negação do caráter histórico e ideológico do ser.

A revolução na Filosofia da Linguagem superou o esquema sujeito-objeto e a ideia da existência de um mundo independente da linguagem, bem como o entendiment o de que a compreensão poderia ocorrer dissociada das questões linguísticas. Dito de outro modo, rompeu com a ideia de um mundo pré-linguístico, em que o sujeito solipsista, por meio de sua subjetividade, poderia apreender a essência das coisas. Desta revolução resultou que "o compreender se dá na e pela linguagem; logo, o conhecimento, que somente ocorre na linguagem, não mais tem a linguagem como um veículo ou uma terceira coisa" (STRECK, 2014, p. 252-278). Distanciou-se, assim, das concepções anteriores por acrescentar a questão da linguagem como ponto central para a constituição do sentido, bem como para a relação do sujeito com os objetos e com o mundo em si.

Embora, num período anterior, a linguagem tenha feito parte das discussões filosóficas, é no século 20 que ela passa a tomar relevância, sobretudo em decorrência da reviravolta linguístico-paradigmática. É a partir do findar daquele século que o Direito passa a recepcionar as teorias da revolução da linguagem (STRECK, 2014, p. 277) desenvolvidas, especialmente, por Heidegger e Gadamer.

O giro ontológico-linguístico, como ficou conhecido, superou os paradigmas impressos pela Filosofia da Consciência, desmistificando as teorias metafísicas e a ideia de que as coisas possuíam uma essência. Ademais, a partir de então, atestou-se a necessidade da concepção do contexto socioprático como possibilidade para a definição do sentido das palavras (STRECK, 2014, p. 245). Desse modo, inseriu-se, por meio da linguagem, o ingrediente da realidade no processo de interpretação e compreensão das normas jurídicas.

O processo de mudanças não se deu de maneira apressada, ao contrário, diversos momentos históricos contribuíram em maior ou menor grau para a sua realização. Três momentos são citados por Streck (2014, p. 240-248) como essenciais para a ascensão linguística na Filosofia, sendo eles: 
a) O neopositivismo lógico, em que o conhecimento científico exigia o rigor linguístico como condição para sua configuração. Vê-se aí o início das discussões mais recentes acerca da linguagem; b) Num segundo momento, a formulação do giro linguístico ocorre, de maneira ainda mais nítida, com Wittgenstein em sua crítica à Filosofia da Consciência. A ideia propagada é a de que o mundo só existe em decorrência da linguagem, não existindo realidade a par dela; c) Num terceiro momento, a Filosofia da Linguagem ordinária, que rompe com o neopositivismo, passando da análise semântico-sintática para a análise pragmática, ou seja, passou a ser vista como componente importante socialmente falando (STRECK, 2014, p. 240-248).

É com Wittgenstein que a linguagem é colocada pela primeira vez como constitutiva da relação com o mundo. Apesar de seu contributo, entretanto, é apenas com Heidegger que há o rompimento da base que sustentava a hermenêutica tradicional. Tal fato pode ser constatado, pois é Heidegger quem considera o homem como homem histórico, tornando este o ponto central do processo de compreensão. A compreensão do ser é reconhecida como condição para a interpretação das coisas que compõem o mundo, em razão de que não existe "uma ponte entre consciência e mundo", o ser já é o próprio ser no mundo (STRECK, 2014, p. 274).

Na base das investigações ônticas (dos entes) e ontológicas (do ser) está a ontologia fundamental de Heidegger, configurando-se como a análise do Dasein, ou seja, da própria compreensão do ser no mundo. Em vista disso, "a questão do ser visa às condições de possibilidade das próprias ontologias que antecedem e fundam as ciências ônticas" (HEIDEGGER, 1989, p. 37). Para Heidegger, a compreensão da condição do ser como ser no mundo é necessária para a correta interpretação dos entes.

Pode-se afirmar que, em Kant, o sujeito é fundamento da verdade. Na hermenêutica filosófica de matriz heideggeriana, há um deslocamento para o mundo enquanto "espaço onde o significado é encontrado e produzido no contexto de um a priori compartilhado" (STRECK, 2013, p. 18-19). O intérprete está inserido em uma realidade que é condição de possibilidade da interpretação. A realidade na qual está inserido influenciará no processo interpretativo, fato este reconhecido pela hermenêutica filosófica. O sujeito compreende para depois interpretar, somente imerso "nas regras do jogo" é que terá condições de interpretar o mundo ao seu redor e, por conseguinte, as normas. Por isso dizer que a interpretação é precedida de uma compreensão prévia, isso porque o Dasein é desde sempre consciente de si próprio. É preciso pré-compreender para compreender.

Desse modo, conforme Heidegger, "a interpretação de algo como algo se funda, essencialmente, numa posição prévia, visão prévia e concepção prévia". Indo além,

a interpretação sempre se funda numa visão prévia que "recorta" o que foi assumido na posição prévia, segundo uma possibilidade determinada de interpretação (...) como quer que seja, a interpretação sempre já se decidiu, definitiva ou provisoriamente, por uma determinada conceituação, pois está fundada numa concepção prévia (HEIDEGGER, 1989, p. 207).

A hermenêutica filosófica afasta por derradeiro a ideia de imparcialidade do intérprete. Ao contrário, enfatiza a presença dos pré-conceitos como constitutivos do próprio processo interpretativo. Ao colocar-se diante de algo que se pretende interpretar (o texto jurídico, por exemplo), o intérprete de antemão antecipa seu significado com base nos pré-juízos que possui. Em contraponto ao paradigma moderno da Filosofia da Consciência, "o método heideggeriano oferece, em realidade, um desvelado caminho de acesso à coisa mesma, sem intermediações de uma consciência-reflexiva que se julga soberana e determinante da diretriz humana" (MARCELLINO JUNIOR, 2007, p. 550).

É a partir de uma postura eminentemente existencial que Heidegger discorre sobre o círculo da compreensão:

o decisivo não é sair do círculo mas nele penetrar de modo correto. Esse círculo do entender não é um círculo comum, em que se move um modo de conhecimento qualquer, mas é a expressão da existenciária estrutura-do-prévio do Dasein ele mesmo. O círculo não deve ser degradado em vitiosum nem ser também tolerado. Nele se abriga uma possibilidade positiva de conhecimento o mais originário, possibilidade que só pode ser verdadeiramente efetivada de modo autêntico se a interpretação entende que sua primeira, constante e última tarefa consiste em não deixar que o ter-prévio, o ver-prévio e o conceber prévio lhe sejam dados por ocorrências e conceitos populares, mas em se assegurar do tema científico mediante sua elaboração a partir das coisas elas mesmas (HEIDEGGER, 1989, p. 433). 


\section{Debate}

Assim, conforme o autor, o intérprete está imerso no círculo hermenêutico e a sua existência antecede a qualquer interpretação, de modo que sempre possui uma compreensão prévia do que pretende interpretar. Deve atuar, portanto, com precaução para que suas pré-compreensões, muitas vezes viciadas, não corrompam as coisas mesmas. As concepções prévias devem ser reavaliadas por meio de um processo crítico que questione as antecipações de sentido. Ao interpretar, o sujeito deve abrir-se ao sentido do texto como forma de obter um conhecimento científico legítimo.

Em suma, o filólogo não se utiliza do método para encobrir a parcialidade do sujeito como pretendeu a metafísica moderna. Em sentido contrário, busca evidenciar sua existência para que se torne consciente e, assim, seja possível tomar o seu controle a fim de obter uma correta compreensão a partir do texto (GADAMER, 2014, p. 146). Para o autor, somente dessa maneira a cientificidade do processo interpretativo poderia ser assegurada. $O$ significado do texto deveria ser colocado em evidência em detrimento dos preconceitos que viciam o processo de aplicação das normas.

O autor revela a finitude do sujeito e, como consequência, os próprios limites da interpretação, estes que são encontrados na historicidade do intérprete. Rompe-se com a figura do sujeito resguardado em sua superioridade racional. Com isso, a derrocada da crença nas verdades absolutas que permeava a modernidade abre espaço para as certezas relativas, as quais dependem da realidade circundante, da vivência e da história (MARCELLINO JUNIOR, 2007, p. 559).

Além disso, é possível falar em uma espécie de comprometimento do intérprete com o que Heidegger chama de coisas mesmas, ou seja, com o texto. O texto normativo é dotado de sentido, o qual deve ser observado em detrimento dos pré-conceitos carregados por quem o interpreta. Destarte, cabe a quem pretende compreender um texto confrontar os seus juízos prévios com os juízos do texto, colocando-os à prova, ou seja, abrindo-se ao texto e deixando que este "Ihe diga algo" (GADAMER, 2014, p. 145).

A hermenêutica proposta por Heidegger rompeu com os cânones metafísicos que sustentavam a ciência moderna. Em decorrência disso, os elementos que buscavam ser encobertos pelo método foram revelados. $O$ jus filósofo propôs uma hermenêutica de orientação ontológica, considerando a compreensão do ser enquanto ser-no-mundo como fundamental para a formação do conhecimento. Nesse processo, incluiu a faticidade como objeto da interpretação para além dos textos.

O método fenomenológico é ponto fulcral da teoria de Heidegger e compreende os termos fenômeno e logos. Aquele significa aquilo que está à mostra, que se pode ver e este uma definição, medida, conceito. Conforme o autor, "a fenomenologia é a via de acesso e o modo de verificação para se determinar o que deve constituir tema da ontologia. A ontologia só é possível como fenomenologia" (HEIDEGGER, 1989, p. 57-66). É por esta razão que o filósofo insiste na importância do sentido do texto como a primeira coisa a ser levada em conta no processo de compreensão.

A teoria existencial de Heidegger desmistifica a ideia de imparcialidade sustentada na modernidade pelo paradigma da Filosofia da Consciência. Para o autor, o reconhecimento da existência dos pré-conceitos do intérprete é essencial para que ocorra a possibilidade de afastá-los em nome de uma interpretação mais legítima e menos viciada que leve em conta o sentido impresso no texto e, sobretudo, a realidade social.

O "ser no mundo", difundido por Gadamer, é que determinará a compreensão e a interpretação da norma. O autor apoia-se em Heidegger e utiliza-se do existente humano para definir o modo pelo qual a compreensão ocorre. Isso deve-se ao fato de que a hermenêutica, que se dá enquanto ser no mundo, ocorre por meio "da faticidade e historicidade do intérprete" (STRECK, 2014, p. 277). Estes dois elementos integram o processo de compreensão pré-definindo o caminho percorrido. Sendo assim, o ideal de imparcialidade da modernidade é, mais uma vez, desmistificado pela hermenêutica filosófica. O sujeito, que aqui não se confunde com o sujeito solipsista da modernidade, participa da constituição do sentido munido com os seus pré-conceitos.

A interpretação ocorre por meio de uma pré-compreensão em que o sujeito interpreta conforme as concepções que já possui. Desse modo, Gadamer trata de um elemento anterior à compreensão: os pré-conceitos. Salienta o autor a necessidade de estar consciente da existência dessa pré-compreensão para que se possa evitar aplicá-la sem maiores reflexões (STRECK, 2014, p. 310). Assim, afasta a ideia de que o método poderia ser utilizado como confirmação das próprias opiniões ou pré-juízos, atestando que, ao contrário, é desejável aprofundar-se nas próprias antecipações a fim de descobrir os pré-conceitos e vencê-los. 
Ante o texto, as opiniões prévias e os preconceitos acompanham o leitor. Gadamer não propõe que estes sejam abandonados no momento da leitura, mas alerta para que o intérprete não fique preso a eles. Existe a exigência de uma abertura para a opinião do texto, de modo que as opiniões próprias do sujeito sejam confrontadas com as do objeto. Gadamer fala em um "solo firme" em que a compreensão pode firmar-se. Este solo nada mais é do que o próprio sentido determinado de antemão pelo texto (GADAMER, 2014, p. 358).

Gadamer chama de história efeitual as condicionantes históricas do pensamento que surgem mesmo que de maneira inconsciente e estão presentes no processo de compreensão. O reconhecimento da existência e da influência da história efeitual poderia evitar que ela viesse a contaminar a compreensão. Desse modo, tal reconhecimento é fundamental para a formação do pensamento científico, não obstante não possa ser absoluto. A históra efeitual é característica da própria situação hermenêutica do homem como ser histórico. Bem por isso, uma consciência absoluta dessa condição não seria possível, pois faz parte da própria essência humana (GADAMER, 2014, p. 398-399).

Em suma, "a compreensão só pode resultar da revisão constante do ponto de partida do intérprete, o que irá permitir que o conteúdo venha à superfície" (BLEICHER, 1980, p. 172). Assim, ao ter consciência de seus pré-conceitos, o intérprete terá condições de revê-los e confrontá-los com o texto. O processo de compreensão pode iniciar maculado de pré-conceitos, porém é desejável que, diante do reconhecimento destes, o intérprete proceda a sua revisão até chegar ao resultado mais adequado para a situação fática.

Conforme Gadamer, "querer evitar os próprios conceitos na interpretação não só é impossível como também um absurdo evidente. Interpretar significa justamente colocar em jogo os próprios conceitos prévios, para com isso trazer realmente à fala a opinião do texto" (2014, p. 514). Nesse ponto percebe-se com nitidez a influência do método fenomenológico de Heidegger em Gadamer. Para este, o texto é um terreno seguro para o qual o intérprete deve voltar-se sempre que notar tendência que o guie a caminho diverso ao que determina. Assim, o texto não é destituído de sentido, constituindo-se em verdadeiro norte do intérprete.

Desse modo, a compreensão resulta do confronto entre a opinião do intérprete e o texto, formando, assim, uma fusão de horizontes, que nada mais é do que "o alargamento do horizonte do sujeito e do horizonte do objeto para uma 'generalidade superior'" (BLEICHER, 1980, p. 159). Colocar em questão os próprios pré-conceitos e as pré-compreensões repassadas por meio da tradição é um exercício de alargamento do horizonte de sentidos.

Em Gadamer, somente por meio da fusão entre um sujeito e um objeto, quando inseridos em sua historicidade, tornar-se-á possível a produção do conhecimento científico. A fusão ocorre mediante a impressão das condições do sujeito no objeto e do objeto no sujeito, um interage com o outro, aproveitando reciprocamente das modificações em si e no outro que ocorrem durante esse processo (GADAMER, 2014, p. 404). Quer dizer que o objeto não é mais o mesmo a partir do contato com o sujeito e este também é modificado pela interação com o objeto.

Levando em conta o fato de que a compreensão ocorre por meio da fusão de horizontes e, portanto, desde o princípio uma análise da realidade é necessária, Gadamer crítica a cisão entre interpretação e aplicação da norma. A crítica de Gadamer vai no sentido de negar a existência de um modelo de interpretação fragmentado, em que se pudessem distinguir os momentos de interpretar e aplicar (STRECK, 2014, p. 276). Assim, para o autor, interpretação e aplicação ocorrem em um mesmo momento, pois não se pode interpretar um texto dissociado da realidade a que ele será aplicado.

O "conteúdo normativo deve ser determinado em relação ao caso em que deve ser aplicado" (GADAMER, 2014, p. 429). Sendo assim, ressalta-se que a interpretação deve ocorrer tendo como base o caso concreto ao qual se destina a resolver. $O$ intérprete é responsável por atribuir um sentido ao texto. Com base nisso, "a pergunta pelo sentido do texto é uma pergunta pelo modo como esse sentido se dá, qual seja, através do intérprete, inserido na tradição, que compreende esse sentido" (STRECK, 2014, p. 304-305). Desse modo, não se trata de reproduzir um sentido anteriormente produzido. Em consequência disso, a interpretação não pode comprometer-se a buscar a "vontade do legislador" embutida no texto legal. O caráter histórico vem à tona com a interpretação, porém de modo diverso, constituindo uma nova realidade no presente.

Após tal constatação, o autor adverte que a compreensão por meio da leitura não se restringe à repetição do que pretendia explanar o autor no momento em que escreveu o texto. Ao contrário, ao intérprete cabe participar da constituição do sentido no momento presente. Outrossim, não seria possível simular as concep- 


\section{Debate}

ções que possuía o legislador ou reproduzir o seu horizonte de sentido, de modo que "o horizonte de sentido da compreensão não pode ser realmente limitado pelo que tinha em mente originalmente o autor, nem pelo horizonte do destinatário para quem o texto foi originalmente escrito" (GADAMER, 2014, p. 508-511).

$\mathrm{Na}$ interpretação própria do positivismo kelseniano, a discricionariedade judicial era uma fatalidade, pois não existiam critérios que delimitassem o âmbito da aplicação da norma e, ao mesmo tempo, estivessem ao alcance do estudo da ciência do Direito. A ideologia do sujeito era negada, resultando em verdadeiro voluntarismo judicial. Ocorre que, ante os novos paradigmas hermenêuticos, a discricionariedade deve ser afastada, pois passou a existir um critério: o da situação hermenêutica. Dessa forma o intérprete, ao confrontar os seus pré-juízos com o sentido do texto, deve sempre ter em mente a realidade fática na qual a norma será aplicada. Tratando-se do Brasil, não há que se olvidar da existência de uma Constituição Social com caráter dirigente e que institui o Estado Democrático de Direito.

Dito isso, cabe analisar se os novos paradigmas hermenêuticos foram ou vêm sendo recepcionados pelo Direito brasileiro ou se o modelo interpretativo de Kelsen ainda é utilizado como referência a permear o inconsciente dos juristas.

\section{A SUPERAÇÃO DO POSITIVISMO NO DIREITO BRASILEIRO POR MEIO DA FILOSOFIA DA LINGUAGEM}

No Direito, o positivismo normativo restou superado pelos ideais neoconstitucionalistas surgidos no pós-Segunda Guerra Mundial. Se antes o conteúdo era suplantado pela forma, agora as normas constitucionais passaram a expressar os objetivos e fundamentos do Estado Democrático. O movimento instituiu a concepção de Constituição como centro normativo de onde emana a legitimidade do Estado. Um documento com o condão de dirigir a atuação do Estado e da sociedade para a efetivação dos direitos constitucionais proclamados, provocando mudanças concretas na realidade político-social.

Nesse sentido, apesar de os países democráticos adotarem uma Constituição detentora de um núcleo normativo e principiológico comum, é resguardada uma parcela de especificidade a elas. Cada país possui um percurso histórico a implicar na formulação do texto constitucional (MORAIS, STRECK, 2010, p. 108). Destarte, a Constituição abarca a realidade do seu tempo, bem como as necessidades mais prementes da sociedade que pretende regular, tornando-se um documento determinante para o presente e, sobretudo, para o futuro do país. Isso na medida em que, além de legitimar a atuação dos entes públicos, institui um plano que vislumbra a construção da sociedade que almeja.

No Brasil, a História mostra que o Estado Social foi ausente para as camadas mais populares. Disso decorre que os direitos sociais prometidos pela modernidade ainda restam sem concretização no país. A população brasileira não usufruiu de forma plena dos benefícios da modernidade, pois "o intervencionismo estatal, condição de possibilidade para a realização da função social do Estado, serviu tão somente para a acumulação de capital e renda em favor de uma pequena parcela da população" (MORAIS; STRECK, 2010, p. 81). No período colonial, o Estado não esteve presente para as camadas populares, não houve diferenciação nítida entre público e privado e a "casa grande" era quem muitas vezes assumia as atividades públicas, inclusive as de governo. O poder econômico era o responsável por estruturar a pirâmide da hierarquia política da época, observando-se que ao topo figuravam os grandes senhores de engenho, que mantinham sob seu poder o restante da população menos favorecida economicamente. Por deterem o poder político da época, os coronéis mantinham sob sua dependência a população pobre, oferecendo bens em troca de favores e obediência (LENARDÃO, 2004, p. 4-8).

Nesse sentido, a Carta de 1988 buscou o resgate dos direitos sociais prometidos e não cumpridos pela modernidade, na medida em que se estabeleceu como uma Constituição essencialmente social, direcionada ao prestacionismo estatal. Tornou-se, portanto, responsável por descrever o caminho a ser perseguido pelo Estado e pela sociedade rumo à concretização dos direitos que proclamou. Nesse sentido, a normatividade constitucional brasileira apresentou-se como transformadora da realidade social e como instrumento modificador do status quo até então experimentado (MORAIS; STRECK, 2010, p. 96). Representa, assim, a "reinvenção do pacto político entre Estado e cidadãos" (LUCAS, 2014, p. 21). Atesta-se com isso a pretensão de eficácia da Constituição, a qual deve ser aplicada na totalidade dos casos que se mostram no acontecer do Estado Democrático. 
A Constituição Federal de 1988 resultou no nascimento de "uma nova era no Direito", isso em decorrência da instituição de uma normatividade deontológica legitimadora das demais normas e da atuação das entidades públicas. Arraigados às regras foram estabelecidos princípios estruturantes do Estado Democrático de Direito, estes que passaram a impor verdadeiras tarefas a serem cumpridas pelo poder público e pela sociedade. Diante dessa era iniciada pela Constituição de 1988 uma nova interpretação fez-se necessária a fim de acompanhar tais avanços. Assim, o afastamento da hermenêutica clássica, que é direcionada à interpretação do Direito privado, um sistema que não admitia antinomias, caracterizado por seu caráter extremamente fechado, é condição essencial para o ingressar em um novo momento normativo (SILVA; TORRES, 2014, p. 2).

Em outras palavras, o acompanhar pelo Direito das mudanças ocorridas na Filosofia da Linguagem é condição para a efetividade do plano instituído pela Constituição de 1988. Em vista disso, "é possível afirmar que, sendo uma norma jurídica válida tão somente se estiver em conformidade com a Constituição, a aferição dessa conformidade exige uma pré-compreensão acerca do sentido de (e da) Constituição" (STRECK, 2004, p. 7). A estrutura prévia que se forma pela compreensão da Constituição é fundamental para a correta interpretação das leis infraconstitucionais. É a chamada filtragem constitucional, que não é uma questão de método, mas, sim, de pré-compreensão do Ser para chegar ao seu Ente. A compreensão da Constituição antecede qualquer interpretação no Estado Democrático.

Desse modo, a recepção do paradigma da Filosofia da Linguagem surge como condição para a eficácia do neocostitucionalismo no Brasil. Para Streck, no entanto, há uma distorção da compreensão do neocontitucionalismo no país. Isso na medida em que este é encarado como uma postura meramente antiformalista, como já defendido pela escola dos Partidários do Direito Livre. Tal concepção leva à adoção do ativismo judicial como se fosse expressão da superação do positivismo (STRECK, 2011, p. 36-37).

Não se desconsidera a relevância do poder Judiciário nesta quadra da história, bem como não há uma defesa à proibição de interpretar. O que é objeto de crítica é a concepção da interpretação como fruto da vontade, das concepções pessoais e da subjetividade do julgador, o que seria um retorno ao positivismo (STRECK, 2013, p. 95). Com isso, um círculo vicioso é formado, na medida em que a interpretação é realizada tomando por base o paradigma subjetivista, resultando, assim, em decisões judiciais que mais têm a ver com o positivismo do que com a realidade atual, ou seja, decisões discricionárias que, não raro, resultam em arbitrariedades, pois carregam, no método, o voluntarismo. Tais decisões são solidificadas por meio das súmulas, criando a ideia de que as próximas questões levadas ao Judiciário podem ser revolvidas por meio delas, como se pudessem abarcar a realidade do caso concreto (STRECK, 2014, p, 424).

Ademais, o ensino jurídico também segue os velhos paradigmas, pois os livros reproduzem o entendimento dos tribunais. O valor da doutrina crítica do Direito deve ser reavaliado, tomando o papel de, efetivamente, doutrinar e desmistificar a ideia de que "o direito é aquilo que o judiciário diz que é" (STRECK, 2013, p. 83). O Direito deve ser ensinado e praticado em conformidade com a Constituição, que é eminentemente social. O direito e a realidade prática não podem dissociar-se ante os exemplos doutrinários fantasiosos ou decisões que seguem a consciência do juiz em detrimento da normatividade constitucional.

Há, portanto, uma crise de paradigmas no Direito, pois, não obstante a Constituição de 1988 ter inaugurado um novo momento normativo, o Direito brasileiro permanece assentado no paradigma subjetivista. A interpretação ainda é encarada como técnica/método para extrair o sentido da norma, com a linguagem sendo considerada uma terceira coisa entre o sujeito e o objeto (STRECK, 2014, p. 381). Impera, ainda, a figura do sujeito cartesiano moderno, que, voltado a si mesmo, sem a influência do mundo externo, descobre a verdade das coisas.

A postura discricionária atual repete o modelo kelseniano de uma época em que a interpretação ocorria tendo como base o Direito privado e o estrito legalismo, sem considerar a realidade social. Nos tempos hodiernos, além de esta postura impedir a efetividade das normas constitucionais, torna latente a insegurança jurídica proveniente do decisionismo jurisdicional. Os Tribunais assumem a missão de "dizer o Direito", en- 
quanto a doutrina e os advogados repetem o já dito. Nessa equação, a Constituição é colocada em segundo plano, ocorrendo que as normas infralegais não passam por uma filtragem constitucional, mas sim a Constituição que acaba sofrendo uma seleção jurisdicional.

A dogmática jurídica assenta razão na tese de que o intérprete extrai o sentido que está, desde sempre, contido na norma, expressando, ademais, que nos casos em que a lei se mostra clara a simples subsunção ao caso concreto é suficiente. Assim, não obstante as mudanças no campo normativo, a interpretação das normas continua seguindo um modelo assentado no esquema sujeito-objeto, seguindo o modelo próprio da Filosofia da Consciência, de modo que a superação deste paradigma faz-se necessária para a concretização dos direitos constitucionais impressos na Carta de 1988.

Isso posto, seguir a normatividade constitucional é um avanço, o vínculo à Constituição é necessário ao desenvolvimento político e social, o que não significa a proibição de interpretar, mas sim o afastamento do sujeito solipsista da modernidade. Apesar disso, a dogmática jurídica vem sustentando a cultura liberal-individualista. Em termos, a Constituição de 1988 é o primeiro diploma constitucional efetivamente democrático e detentor de ampla gama de direitos sociais no Brasil. Em decorrência disso, a pré-compreensão dos juristas permanece assentada da cultura subjetivista moderna, podendo-se citar a existência de um Código Penal que data de 1940 e é aplicado sem a devida filtragem constitucional (STRECK, 2014, p. 382). Percebe-se que o sentido da Constituição permanece velado, na medida em que os paradigmas que a sustentam não foram recepcionados pelo Direito. Destarte, o rumo tomado pelo Judiciário atual destoa do novo modelo, na medida em que permanece indo no sentido dos postulados positivistas, apostando na discricionariedade do juiz (BOLESINA; GERVASONI, 2014, p. 1).

Somente o sujeito consciente de sua própria historicidade poderá exercer uma reflexão crítica acerca da compreensão. Como já mencionado, a realidade da experiência forma o horizonte da pré-compreensão necessário à interpretação. Essa pré-compreensão, entretanto, pode (e deve) ser ampliada para conter novos conteúdos de sentido (OLIVEIRA, 1996, p. 230-231). O horizonte de sentido do intérprete deve abarcar o conteúdo da Constituição em meio ao Estado Democrático de Direito como pré-compreensão necessária à interpretação de qualquer outra norma que se coloque como válida. Em consonância, "interpretar é compreender. E compreender é aplicar. A hermenêutica não é mais metodológica. Não mais interpretamos para compreender, mas sim, compreendemos para interpretar" (STRECK, 2013, p. 77).

Desse modo, a superação do positivismo no Brasil passa pela observância de dois requisitos fundamentais: o conhecimento do que significaram os positivismos - normativo e exegético - e o abandono na discricionariedade judicial. Somente dessa maneira poder-se-á falar em pós-positivismo. Enquanto isso, se continuará vivendo sob o manto do Estado Democrático, com uma das mais modernas Constituições do mundo sem que ela seja sentida na prática, quer dizer: sem que tenha sua força normativa efetivada.

\section{CONSIDERAÇÕES FINAIS}

A afirmação da autonomia do Direito e a construção da ideia de ordenamento jurídico representam contribuições realizadas por Kelsen e que são fundamentais para a Ciência Jurídica, Em prol do seu objetivo de construir uma teoria do Direito pura, no entanto, o austríaco precisou admitir que a norma não necessitaria ser submetida à provação prática, bastando a conformidade formal. Destarte, o autor não enfrentou a razão prática do Direito, concentrando-se apenas na razão teórica. Nesse processo, admitiu que o juiz pudesse decidir de qualquer maneira, escolhendo uma entre as várias opções fornecidas pela moldura normativa, sem que a Ciência Jurídica pudesse controlar sua decisão.

Desse modo, o modelo de interpretação de Kelsen, apresentado na Teoria Pura do Direito, é um modelo discricionário no que tange à atuação do juiz. Assentou-se na ideia de sujeito criado na modernidade, quer dizer, no sujeito solipsista de Descartes, que existe a par do mundo e está imerso em sua própria racionalidade superior. Nesse sentido, a Teoria da Interpretação de Kelsen nasceu apoiada no paradigma da Filosofia da Consciência. 
Ocorre que, como analisado, a Filosofia foi tomada por uma revolução, na medida em que o paradigma da consciência restou superado pelo paradigma da linguagem. O giro ontológico-linguístico caracterizou-se pelo reconhecimento da linguagem enquanto constitutiva do mundo e do ser enquanto ser-no-mundo. Heidegger passou a análise da compreensão para a ontologia, ou seja, para a análise do ser em detrimento do ente, sendo que a compreensão do ser antecede qualquer interpretação. Gadamer utilizou do existencial de Heidegger para desenvolver o processo hermenêutico ocorrido nesse contexto.

Ante os novos paradigmas hermenêuticos, a discricionariedade deve ser afastada, pois passou a existir um critério: o da situação hermenêutica (STRECK, 2014). Dessa forma, o intérprete, ao confrontar os seus pré-juízos com o sentido do texto, deve sempre ter em mente a realidade fática na qual a norma será aplicada. Tratando-se do Brasil, não há que se olvidar da vigência de uma Constituição Social com caráter dirigente e que institui o Estado Democrático de Direito.

Percebeu-se, entretanto, que, no Brasil, não obstante presente uma Constituição Social, com força normativa e instituidora do regime democrático, os direitos por ela proclamados carecem de efetividade. Isso deve-se a uma crise de paradigmas, pois o velho paradigma moderno subjetivista continua norteando o processo de interpretação das normas. Desse modo, o giro ontológico-linguístico não foi recepcionado no Brasil e, portanto, o modo de fazer Direito segue, ainda, o modelo positivista de Kelsen, assentado no subjetivismo moderno.

A discricionariedade está presente na doutrina e na jurisprudência, representada pelo sistema de precedentes ou pelo dizer corriqueiro de que o Direito é o que os juízes dizem, para citar alguns exemplos. A falta de compreensão acerca da produção de Kelsen e da diferença existente entre positivismo exegético e positivismo normativo levou à crença em um neoconstitucionalismo distorcido que não faz mais do que reafirmar os velhos postulados do positivismo discricionário, a crítica atual continua a ser sobre o positivismo exegético, já superado pelo positivismo normativo (STRECK, 2014, p. 76). Desse modo, critica-se o juiz "positivista", considerado aquele que decide por meio de uma postura estritamente legalista. Para combater esse juiz "atrasado", que se encontra preso ao texto, surge o juiz discricionário, ao qual é permitido interpretar conforme os seus próprios juízos e valores, tudo isso sob o pretexto de evitar retrocessos econômicos, sociais, etc.

Somente o conhecimento sobre quais foram as formas de positivismo e o abandono da discricionariedade judicial poderá conferir efetividade à Constituição brasileira, inaugurando, assim, a era do pós-positivismo no Brasil.

\section{REFERÊNCIAS}

BASILE, Rafael Faria; LAGES, Cíntia Garabini. Interpretação jurídica como ato de conhecimento e ato de vontade: uma análise crítica acerca da teoria interpretativa da teoria de Hans Kelsen. In: ENCONTRO NACIONAL DO CONPEDI, 21., 2012, Uberlândia, UFU, Anais [...].Uberlândia: UFU, 2012. Disponível em: http://www.publicadireito.com.br/artigos/?cod=6ba3af5d7b2790e7. Acesso em: 10 jul. 2017.

BEDIN, Gilmar Antonio; LUCAS, Doglas Cesar. O positivismo maduro e o projeto de construção de uma teoria pura do direito: uma aproximação do núcleo central do pensamento de Hans Kelsen. In: GELAIN, Itamar Luís (org.). Uma introdução à filosofia do direito. Ijuí: Editora Unijuí, 2015. p. 213-238.

BLEICHER, Josef. Hermenêutica contemporânea. Rio de Janeiro: Edições 70, 1980.

BOBBIO, Norberto. O positivismo jurídico: lições de filosofia do direito. São Paulo: Cone, 2006.

BOLESINA, Iuri; GERVASONI, Tássia. Constitucionalismo contemporâneo e hermenêutica: novas perspectivas, velhas dúvidas e o positivismo (solipsista) que anima o ativismo judicial no Brasil. In: CONGRESSO NACIONAL DO CONPEDI, 22., 2014, Florianópolis. Anais [...]. Florianópolis: UFSC. Disponível em: http://www.publicadireito.com.br/artigos/?cod=6b339b7d02cfba05. Acesso em: 2 set. 2017.

BRASIL. Supremo Tribunal Federal. Agravo Regimental em Ação Cautelar no 4.327. Agravante: Aécio Neves. Agravado: Ministério Público Federal. Relator: ministro Marco Aurélio. Brasília, 2017.

BRASIL. Supremo Tribunal Federal. Habeas Corpus no 118.533. Paciente: Ricardo Vieira de Souza. Coator: Superior Tribunal de Justiça. Relator: ministra Carmem Lúcia. Brasília, 2016. 
BRASIL. Supremo Tribunal Federal. Habeas Corpus no 126.292. Paciente: Márcio Rodrigues Dantas. Coator: relator do HC no 313.021 do Superior Tribunal de Justiça. Relator: ministro Teori Zavascki. Brasília, 2016.

CADEMARTORI, Sérgio; GOMES, Nestor Castilho. A teoria da interpretação jurídica de Hans Kelsen: uma crítica a partir da obra de Friedrich Müller. Revista Seqüência, Florianópolis, n. 57, p. 95-114, dez. 2008. Disponível em: https://periodicos.ufsc.br/ index.php/sequencia/article/view/2177-7055.2008v29n57p95. Acesso em: 22 abr. 2017.

CATÃO, Adrualdo de Lima. A interpretação dos fatos no direito na obra de Hans Kelsen. Pima Facie, Maceió, v. 8, p. 97-121, jul./ dez. 2009. Disponível em: http://periodicos.ufpb.br/index.php/primafacie/article/view/4522. Acesso em: 24 abr. 2017.

CUNHA, Ricardo Almagro. Hermenêutica jurídica em Kelsen: apontamentos críticos. Revista de Informação Legislativa, Brasília, a. 45, n. 180 out./dez. 2008. Disponível em: http://www2.senado.leg.br/bdsf/item/id/176576. Acesso em: 22 abr. 2017.

DALLA BARBA, Rafael Giorgio; STRECK, Lenio Luiz; TASSINARI, Clarrisa. As raízes filosóficas do pensamento de Hans Kelsen e suas consequências para o Direito. Revista do Instituto de Hermenêutica Jurídica, Belo Horizonte, ano 14, n. 20, p. 15-28, jul./ dez. 2016.

DESCARTES, René. Meditações metafísicas. 2. ed. Tradução Maria Ermantina Galvão. São Paulo: Martins Fontes, 2005.

FERRAZ JÚNIOR, Tércio Sampaio. Introdução ao estudo do direito: técnica, decisão, dominação. 4. ed. São Paulo: Atlas, 2003.

FERRAZ JÚNIOR, Tércio Sampaio. Por que ler Kelsen, hoje. In: COELHO, Fábio Ulhoa. Para entender Kelsen. São Paulo: Saraiva, 2001.

GADAMER, Hans Georg. Verdade e método I: traços fundamentais de uma hermenêutica filosófica. 14. ed. Rio de Janeiro: Vozes, 2014.

GOMES, Alexandre Travessoni. O fundamento de validade do direito: Kant e Kelsen, 2. ed. Belo Horizonte: Mandamentos, 2004.

GUGEL, Gabrielle Tesser. O paradigma da verdade que perpassa as metafísicas clássica e moderna e determina as decisões judicias. Revista Eletrônica do Curso de Direito da UFSM, Santa Maria, v. 9, n. 1, p. 116-140, 2014. Disponível em: https://periodicos.ufsm.br/revistadireito/article/view/13612. Acesso em: 15 jul. 2017.

HEIDEGGER, Martin. Ser e tempo. 3. ed. Rio de Janeiro: Vozes, 1989.

;. KANT, Immanuel. Crítica da razão pura. São Paulo: Nova Cultural, 1987. Vol. I.

KELSEN, Hans. Teoria Pura do Direito. São Paulo: Martins Fontes, 2000.

LENARDÃO, Elsio. Gênese do clientelismo na organização política brasileira. Lutas Sociais. São Paulo, n. 11/12, 2004. Disponível em: https://revistas.pucsp.br/index.php/ls/issue/view/1205. Acesso em: 30 abr. 2018.

LUCAS, Doglas Cesar. Hermenêutica filosófica e os limites do acontecer do direito numa cultura jurídica aprisionada pelo "procedimentalismo metodológico". Revista do Instituto de Hermenêutica Jurídica: RIHJ, Belo Horizonte, v. 12, n. 15, p. 35-59, jan./ jun. 2014. Disponível em: https://bdjur.stj.jus.br/jspui/handle/2011/81969. Acesso em: 30 abr. 2018.

MARCELLINO JUNIOR, Julio Cesar. O giro linguístico contemporâneo e os contributos de Heidegger e Gadamer: o renascer da hermenêutica jurídica. Revista Eletrônica Direito e Política, Itajaí, v. 2, n. 3, 3 quadrimestre de 2007. Disponível em: www.univali.br/direitoepolitica. Acesso em: 2 dez. 2017.

MARCONDES, Danilo. Iniciação à história da filosofia: dos pré-socráticos a Wittgenstein. ed. 13. Rio de Janeiro: Jorge Zahar, 2007.

MATOS, Andityas Soares; MILÃO, Diego Antonio. Decisionismo e hermenêutica negativa: Carl Schmitt, Hans Kelsen e a afirmação do poder no ato interpretativo do direito. Revista Sequência, Florianópolis, n. 67, p. 111-137, dez. 2013. Disponível em: http://www.scielo.br/pdf/seq/n67/05.pdf. Acesso em: 14 mar. 2017.

MORAIS, José Bolzan de; STRECK, Lenio Luiz. Ciência política e teoria do estado. 7. ed. Porto Alegre: Livraria do Advogado, 2010.

OLIVEIRA, Manfredo Araújo de. Reviravolta lingüístico-pragmática na filosofia contemporânea. São Paulo: Loyola, 1996.

PEDRON, Flávio Quinaud. O giro linguístico e autocompreensão da dimensão hermenêutico-pragmática da linguagem jurídica. Revista Eletrônica do Curso de Direito - PUC Minas Serro, Belo Horizonte, n. 3, p. 174-190, 2011. Disponível em: http://periodicos.pucminas.br/index.php/DireitoSerro/issue/view/169. Acesso em: 15 jul. 2017.

PLATÃO. Crátilo: diálogo sobre a justeza dos nomes. 2. ed. Lisboa: Sáda Costa, 1994.

SILVA, Maria Fontes; TORRES, Cláudia Vechi. Hermenêutica constitucional: avanços e desafios na sociedade contemporânea. In: CONGRESSO NACIONAL DO CONPEDI - UFSC, 22., 2014, Florianópolis. Anais [...]. Florianópolis: UFSC. Disponível em: http:// www.publicadireito.com.br/artigos/?cod=4a7ad6a4dfd49733. Acesso em: 7 set. 2016.

STRECK, Lenio Luiz. Aplicar a "letra da lei” é uma atitude positivista? Revista Novos Estudos Jurídicos-NEJ, Univali, v. 15, n. 1, p. 158-173, jan./abr. 2010.

STRECK, Lenio Luiz. Hermenêutica jurídica $e(m)$ crise: uma exploração hermenêutica da construção do direito. 11. ed. Porto Alegre: Livraria do Advogado, 2014. 
STRECK, Lenio Luiz. Jurisdição constitucional e hermenêutica: uma nova crítica do direito. 2. ed. Rio de Janeiro: Forense, 2004. STRECK, Lenio Luiz. O que é isto - decido conforme minha consciência? 4. ed. Porto Alegre: Livraria do Advogado, 2013. STRECK, Lenio Luiz. Verdade e consenso: constituição, hermenêutica e teorias discursivas. 4. ed. São Paulo: Saraiva, 2011. WARAT, Luis Alberto. A pureza do poder: uma análise crítica da teoria jurídica. Florianópolis: UFSC, 1983.

WARAT, Luis Alberto. Introdução geral ao direito II: a epistemologia jurídica da modernidade. Porto Alegre: Fabris, 1995. 